\title{
Византийский неоплатонизм и западная средневековая мистика: реминисценции христологии Максима Исповедника в учении Бернарда Клервоского
}

\author{
А. В. Тимофеев \\ Национальный Горный Университет, Кафедра Философии и Педагогики \\ Днепр, Украина \\ 201119741974@mail.ru
}

\begin{abstract}
А. В. Тимофеев, Byzantine Neoplatonism and Western medieval mysticism: reminiscences of Christology Maximus the Confessor in the mystical doctrine of Bernard of Clairvaux, Elpis, 19 2017: 35-42.

А. В. Тимофеев, Bizantyjski Neoplatonizm i Zachodnia średniowieczna mistyka: wspomnienia chrystologii Maksyma Wyznawcy w mistycznej doktrynie Bernard z Clairvaux, Elpis, 19 2017: xx-xx.
\end{abstract}

\begin{abstract}
The article considers the correlation between the Christological doctrine of Maximus the Confessor and mystical teachings of St. Bernard of Clairvaux. Analyzed the ideological parallels provisions on synergies divine and human will, sequence degrees of freedom and Christian love in the teachings Christian thinkers.

Streszczenie: W artykule autor rozważa korelację pomiędzy doktryną chrystologiczną Maksyma Wyznawcy a mistyczną nauką świętego Bernarda z Clairvaux. Analizie poddano ideologiczne paralele dotyczące synergii boskiej i ludzkiej woli oraz stopnie sekwencji wolności i miłości chrześcijańskiej w naukach chrześcijańskich myślicieli.
\end{abstract}

\begin{abstract}
Аннотация: В статье рассматриваются корреляционные связи между христологической доктриной Максима Исповедника и мистическим учением св. Бернарда Клервоского. Анализируются идейные параллели положений о синергии божественной и человеческой воли, стадиальности свободы и христианской любви в учениях христианских мыслителей.
\end{abstract}

Keywords: Byzantine Neoplatonism, Western medieval mysticism, grace, free will, synergy, stages of love

Słowa kluczowe: bizantyjski neoplatonizm, zachodnia średniowieczna mistyka, łaska, wolna wola, synergia, etapy miłości

Ключевые слова: византийский неоплатонизм, западная средневековая мистика, благодать, свобода воли, синергия, ступени любви

В современном кризисном состоянии украинского государства и общества, искусственно разделенного по национально-языковой идентичности барьерами информационной войны, все отчетливее звучит призыв к примирению людей, независимо от их идеологических, религиозных и политических предпочтений. Единение людей доброй воли на основе идейных принципов христианской духовности представляется нам важнейшим фактором, дающим возможность находить пути примирения. То, что объединяет христиан - больше, чем то, что их разделяет. В данном контексте исследование влияния идей византийского неоплатонизма на западную средневековую мистику позволяет обосновать неразрывность христианской традиции в ее глубинных основаниях. В данном исследовании будут рассмотрены реминисценции идей византийского неоплатоника Максима Исповедника в учении средневекового французского мистика Бернарда Клервоского в контексте единства оснований христианской духовности.
Бернард Клервоский (1090(91) - 1153 гг.), мистик и религиозный писатель, цистерцианский монах, канонизированный Католической Церковью в 1174 г., а в 1830 г. провозглашенный Учителем Церкви, безусловно, не может считаться православным автором. Твердый приверженец папской теократии, вдохновитель второго крестового похода, диктовавший свою волю королям и папам своего времени, святой Бернард обладал колоссальным авторитетом в церковных и светских кругах Западной Европы первой половины XII века. При этом, несмотря на формальное прекращение отношений между Папством и Православной церковью, аббат монастыря Клерво сохранил в своей духовной доктрине многие изначально православные черты. Рассматривая теоретические источники мистического учения св. Бернарда, зарубежные исследователи (К. Батлер, Э. Жильсон, М. Кейси, Ж. Леклерк, Б. МакГинн, Д. Маслов, Дж. Эванс и др.) отмечают близость его воззрений идеям православных авторов, таких как Антоний Великий, Макарий Египетский, 
Григорий Нисский, Максим Исповедник. В современном диалоге эпох, культур и конфессий актуальным представляется исследование влияния идей представителей византийского неоплатонизма на формирование философско-теологических воззрений св. Бернарда в контексте неразрывности христианской традиции в монашеской культуре средневековой Европы первой половины XII века.

Целью исследования является экспликация реминисценций христологии преп. Максима Исповедника в учении Бернарда Клервоского в контексте единства идейных оснований христианской духовности. Задания, раскрывающие цель статьи: определить идейные параллели между доктриной диофелитства Максима Исповедника и мистическим учением о слиянии двух воль Бернарда Клервоского, выявить историко-генетическую связь философских концепций о стадиальности свободы и степенях христианской любви в учениях преп. Максима и св. Бернарда. В связи с тем, что учение выдающегося учителя Западной Церкви малоизучено в украинской историко-философской науке, методология исследования подразумевает обращение к сочинениям св. Бернарда Клервоского, исследованиям зарубежных авторов, а также применение компаративистского, историко-проблемного и историко-генетического анализа в рамках историко-философской методологии.

Широкую известность идеи византийских неоплатоников в Западной Европе приобрели благодаря переводам на латинский язык произведений Дионисия Ареопагита, Максима Исповедника и Григория Нисского, сделанных в IX в. Иоанном Скотом Эриугеной. Не ограничиваясь переводом, Эриугена в синтезе христианской и неоплатонической традиции создал собственную философскую систему, которая впервые своей целостностью предвосхитила появление схоластики. Разделяя все сущее, определенное понятием «природа», на четыре формы (несотворенную и творящую, сотворенную и творящую, сотворенную и не творящую, несотворенную и не творящую), Эриугена заимствовал основную идею «разделения природы» вместе с терминологией от Максима Исповедника ${ }^{1}$, учение которого становится популярным не только на Востоке, но и на Западе. И если некоторые западные ученые видят заслугу самого Максима преимущественно как комментатора и популяризатора «Ареопагитик», то в отечественных исследованиях его называют в собственном смысле творцом византийской мистики. Указывая на преимущество мистики Исповедника в антропологическом и этическом аспектах, совершенно не затронутых Дионисием Ареопагитом, С. Епифанович называет систему Максима «высоко оригинальной, делающей заметный шаг вперёд по сравнению с самыми выдающимися из своих предшественников»²; Ю. Черноморец пишет, что Максим Исповедник создал «новую мета-

\footnotetext{
Иоанн Скот Эриугена. Жизнь и творения // http://anthropology. rchgi.spb.ru/eriugena/eriugena_b.htm/. Дата обращения 20160620 .

Епифанович С.Л. Преп. Максим Исповедник и византийское богословие. Москва: Мартис. 1996. С. 153-154.
}

физику, которая преодолев ареопагитизм, стала ключом для метафизичного понимания антиметафизичных Ареопагитик на долгие столетья»'; А. Вертеловский отмечает, что преподобный Максим «содействовал более гармоничному примирению спекулятивного и практического направления мистики, развивавшихся до него самостоятельно в лице св. Дионисия Ареопагита и Макария Египетского, и по своему миросозерцанию занимает золотую середину между ними» ${ }^{4}$.

В центре интересов византийского мыслителя находится проблема человека, тесно связанная с жизнью Иисуса Христа (которая суть не только исторические события, но и символы космических процессов), воплощением Слова, теорией обожения и синергии. Сочетая идеи платоновской философии, категории Аристотеля с метафизикой «внутреннего опыта» древнехристианской традиции, Максим Исповедник создал оригинальное учение, востребованное не только православием, но и западными средневековыми мыслителями, прежде всего - мистиками.

На наш взгляд, оценивая влияние византийского неоплатонизма на философско-теологические воззрения Бернарда Клервоского, следует согласиться с мнением Э. Жильсона в том, что влияние Дионисия Ареопагита, высоко ценимого последующими западноевропейскими мистиками, в учении Бернарда практически не прослеживается ${ }^{5}$. Французский медиевист отмечает, что философский язык трудов Дионися совершенно чужд терминологии Бернарда. «Слово “теофания”, почти неизбежное для писателя, знакомого с Дионисием, встречается лишь один раз у Гильома де Сен-Тьерри, и, кажется, не имеет места в лексиконе св. Бернарда»,пишет Э. Жильсон ${ }^{6}$. Несомненно, Бернард был знаком, как с переводами Эриугены, так и с его произведением «De Divisione Naturae». Однако, как отмечает Вл. Татаркевич, «в то же время Бернард не использовал идеи мистиков-пантеистов, вдохновлявшихся Плотином, таких как Псевдо-Дионисий и Эриугена» ${ }^{7}$.

По-видимому, существенное влияние на формирование учения Бернарда оказали идеи Максима Исповедника. Утверждать это можно по нескольким причинам. Во-первых, св. Бернард заимствует у преп. Максима термин, который он использует для обозначения экстаза: «ехcessus». Во-вторых, Бернард Клервоский описывает слияние человеческой воли с Божественной (души с Богом), используя те же образы, что и Максим Исповедник. В-третьих, как отмечает

Чорноморещь Ю.П. Візантійський неоплатонізм від Діонісія Ареопагіта до Геннадія Схоларія. Київ: Дух і Літера. 2010. С. 52. [Перевод мой - А.Т.]

4 Вертеловский А.Ф. Западная средневековая мистика и отношение ее к католичеству. Харьков: Типография Окружного Штаба. 1888. C. 55 .

Gilson E. The mystical theology of Saint Bernard. New York: Sheed \& Ward. 1940. P. 25-28.

6 Gilson E. Ibid. P. 25.

Татаркевич Вл. История философии. Т. 1. Античная и средневековая философия. Пермь: Изд-во Пермского университета. 2000. C. 344 . 
Э. Жильсон, «последовательность идей, общая для обеих доктрин, подчеркивает их переход от Максима к Бернарду ${ }^{8}$. Следует добавить, что, по нашему мнению, Бернард Клервоский в своей трактовке мистического воссоединения человека с Богом посредством «слияния двух воль» идейно близок учению Максима Исповедника о двух волях во Христе, которое преподобный защищал в VII веке. Рассмотрим кратко в историко-философском дискурсе основные темы учения преподобного Максима Исповедника, оказавшие влияние на воззрения святого Бернарда Клервоского.

Подробное исследование формирования и принятия Церковью доктрины диофелитства, разработанной Максимом Исповедником, потребовало бы специальной и весьма объемной работы, поэтому здесь будут представлены лишь основные положения учения преп. Максима о двух волях во Христе 9 . Российский исследователь В.М. Лурье так характеризует период христологических диспутов, в которых Максиму Исповеднику принадлежала важнейшая роль: «Предметом особого интереса в Византии VI-VII веков выступал вопрос христологический. В отношении историко-философском события VII века означали революцию. Концептуальная революция как наблюдаемый извне феномен - вот чем была церковная история VII века, если характеризовать ее на языке истории философии» ${ }^{10}$. В споре с монофизитами, отрицавшими реальность человечества Христа и монофелитами, признававшими в Нем одну волю, Максим защищал свою догматическую систему (за что и был назван Исповедником), которая и была принята Церковью на Шестом Вселенском соборе в 681 г.

Для Максима Исповедника и его последователей, божество и человечество, как две природы Христа не есть лишь отвлеченные понятия, практически слитые воедино в Божестве Слова, как считали монофелиты. По утверждению Максима, каждая природа имеет собственное проявление, и Христос воспринял полноту человеческой природы, в том числе и волю. При этом человеческая природа Христа обладает собственным существованием, «волей», даже если она полностью послушна Божественной. И если Христос свободно послушен Отцу, то и задача человека - привести свою волю в гармонию с Божественной ${ }^{11}$. Духовная миссия

\footnotetext{
Gilson E. Ibid. P. 26.

По данному вопросу см.: Лурье В.М. История Византийской философии. Формативный период. Санкт-Петербург: Axiôma, 2006. С. 289-404; Прот. И. Мейендорф. Святой Григорий Палама и православная мистика. Учение об обожении: Свят. Григорий Нисский и преп. Максим // http://predanie.ru/lib/book/129694/\#toc1.; Болотов В.В. Лекции по истории древней церкви. Tом IV. История церкви в период вселенских соборов. Санкт-Петербург: Типография М. Меркушева. 1918. С. 473-500; Лейн Т. Христианские мыслители. Санкт-Петербург: Мирт. 1997. С. 76-77.

10 Лурье В.М. История Византийской философии. Формативный период. Санкт-Петербург: Аxiôma, 2006. С. 310.

${ }_{11}$ См. Прот. И. Мейендорф. Святой Григорий Палама и православная мистика. Учение об обожении: Свят. Григорий Нисский и преп. Максим // http://predanie.ru/lib/book/129694/\#toc1. Дата обращения 20160623.
}

первого человека, по Максиму Исповеднику, в том и состояла, чтобы соединить с Божеством не только свою волю, но и весь мир, преодолев разделения, возникшие в результате сотворения всего существующего. Совершив дело нашего спасения, Христос реализовал великое назначение человека - привести все тварное бытие к объединению с Богом и обожению. Это объединение, как и все дело нашего спасения, Он произвел Своей человеческой (не затронутой грехом) волей через естественное устремление к Богу и воссоединение Своего произволения с волей Божьей. Такая точка зрения с необходимостью требовала признания человеческой воли во Христе. Подтверждение своей теории Исповедник находит в догмате о Троице. «Личности Троицы имеют общую волю, так как разделяют между собой общую природу, следовательно, и у Христа есть две воли, т.к. у Него две природы» ${ }^{12}$. Отметим, что доктрина диофелитства, разработанная Максимом Исповедником, была догматизирована на VI Вселенском соборе для халкидонских церквей (Римско-католическая и Восточные православные церкви).

Утверждением своего учения Максим Исповедник сделал большой вклад в становление христианской антропологии, христианского видения человека. Человек - свободное существо, драма этого мира - драма свободы: по свободе человек уходит от Бога и по свободе возвращается. Неоплатоническая модель исхода и возвращения в таком прочтении характерна и для антропологии Бернарда.

Аббат монастыря Клерво, высказывая идеи, близкие учению преп. Максима, использует дистинкцию образа и подобия. Созданный по образу Бога, в результате неправильного использования свободной воли, человек, по сути, сослал себя из Страны Подобия, в Землю Несходства, Страну Неподобия (Regio Dissimilitudinis). Созданный Богом и для Бога, человек обратился к преходящим вещам тварного мира, где в поисках утоления желания обретения материальных благ вращается в порочном круге алчности. Здесь, по выражению Бернарда, человек находится в изгнании. Он больше не обитает в стране своего рождения. Возвращение на родину зависит от правильного выбора объекта желания (или скорее, в трактовке Бернарда Клервоского, - «объекта любви»), которым является только Бог.

Примечательно, что Бернард Клервоский, как и преподобный Максим Исповедник, следуя древнехристианской традиции, считает свободу воли образом

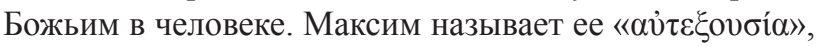
что буквально переводится на славянский как «самовластие», а на русский - «свобода» (в значении свободы воли) ${ }^{13}$. Созданный в свободе (свободным творческим актом Бога), человек должен был становиться в свободе, и грехопадение он совершил в свободе. Падение

\footnotetext{
12 Лейн Т. Христианские мыслители. Санкт-Петербург: Мирт. 1997. C. 77 .

13 Лурье В.М. Там же. С. 385.
} 
есть акт воли, следовательно, и грех, прежде всего, - в воле. По мнению преподобного Максима, грех - ложная направленность (интенция) воли, уклонившейся мимо Бога к небытию. Зло, считает Максим, как «вещьв-себе» не существует, оно реально лишь в свободном извращении разумной воли: «Зло есть не-сущее, прежде всего как это устремление или воля к небытию» ${ }^{14}$. Человек, избранный привести весь мир к Богу, избрал небытие. Воля, как источник греха ветхого Адама, более всего требовала восстановления, и спасение не совершилось бы, если бы Христом не была воспринята и исцелена воля. И поэтому человеческая воля во Христе не только реальна, но и выступает аксиологическим эталоном, мерилом совершенства и чистоты. Не затронутая грехом, внутренне единая, не подверженная колебаниям и противоречиям, человеческая воля Христа внутренне согласуется с волей Божества в цельности и простоте как высшая мера свободы. Эту высшую степень свободы преп. Максим видит в библейском обращении Спасителя к Своему Отцу: «Отче Мой! Если возможно, да минует Меня чаша сия: впрочем не как Я хочу, но как Ты» (Матф. 26:39), и в христианской молитве: «Да будет воля Твоя, яко на небеси и на земли».

Бернард Клервоский приводит эти строки молитвы в трактате «О любви к Богу», говоря о высшей ступени любви: «И будет радовать нас не столько удовлетворение наших нужд и обретение нами счастья, сколько исполнение Его воли в нас и нами. Это то, что мы просим каждодневно в молитве, говоря: “Да будет воля Твоя и на земле, как на небе"»» ${ }^{15}$.

Принцип стадиальности обретения свободы как восхождения по ступеням любви в учениях преп. Максима и св. Бернарда будет рассмотрен нами далее. Здесь же следует отметить, что в понятие «воля» Максим не вкладывал того значения, которое оно имеет в современной философии персонализма. Для Максима Исповедника воля - синоним энергии, в которой и проявляется подлинное существование ${ }^{16}$. Такой же экзистенциальный характер понимания волевых моментов присутствует и в философских построениях Бернарда. Для Бернарда Клервоского человек - прежде всего существо желающее, свободное в своем выборе. Интенциональность воли посредством свободы выбора объективируется в акте согласия, как движение к чему-то другому, проецирующему себя вовне прежде всякого нравственного рассуждения. Связывая это стремление с динамикой восстановления человека, Бернард мыслит в согласии со святоотеческой традицией, когда подчеркивает роль воли в триаде грехопадение-восстановление-обожение.

В теории волевого акта преподобный Максим Исповедник различает природную и гномическую волю.

\footnotetext{
14 См. Флоровский Г.В. Византийские Отцы V-VIII веков: из чтений в Православном богословском институте в Париже. Москва: Паломник. 1992. С. 137.

15 Бернард Клервоский. Трактаты. О любви к Богу. О благодати и свободном выборе. Санкт-Петербург: Изд-во РХГА. 2009. С. 95.

16 Прот. И. Мейендорф. Там же.
}

Природная воля есть одинаково свойственное каждому разумному существу некое стремление. Это «стремление» есть, в то же время, и «сила», то есть именно «потенция», «способность», которая может осуществиться ${ }^{17}$. В отличие от воли природной $(\theta \dot{\lambda} \lambda \eta \mu \alpha)$, гномическая воля ( $\gamma v \omega ́ \mu \eta)$ является личной, относящейся к конкретной ипостаси, и у каждого человека она - своя. Она предшествует окончательному выбору решения и определяет его. Именно личная воля дает направление вектору воли, определяя направление желания человека. Гномическая воля включает в себя процесс поиска, анализа и колебаний выбора. Максим Исповедник сравнивает природную и личную волю с природной способностью видеть и с направлением зрения в ту или иную сторону ${ }^{18}$. Последняя стадия волевого акта окончательное решение и утверждение в нем.

Поскольку цель человека - достижение единения с Богом, то и оптимальное направление гномической воли соответствует направлению Божьей воли. Такая ориентация была присуща Спасителю и святым, которые достигли обожения: «Они соработники у Бога в деле осуществления Его Промысла» (Быт. 18:20 - 33). Таким образом, в обожении человек имеет те же самые воли, что и Христос: две природные воли, то есть - божественную и «прикрепленную» к ней человеческую, но без всякой гномической воли:

- $\quad$ во Христе: природная воля Бога + природная воля человека;

- в человеке: природная воля человека + гномическая воля;

- в обоженном человеке: природная воля Бога + природная воля человека.

В.М. Лурье подчеркивает принципиальное совпадение первой и последней строк - воль во Христе и в обоженном человеке ${ }^{19}$. Встреча конечного и бесконечного, Бога и творения осуществилась во Христе, однако человеческая природа не растворилась, не была преодолена и не превратилась в простую схему «феномена». Преподобный Максим в своем учении сохраняет бытийное право «человеческого» как в природе Христа, так и в обычных людях, полагая основной закон христианской жизни в подражании Христу, подчеркивая личностное начало в обожении.

По мнению Максима, падение воли состоит в том, что была утеряна ее целостность и простота, что воля из интуитивной превратилась в дискурсивную и разворачивается в сложный, множественный процесс поиска, апробации, выбора. «Выбор» отнюдь не является необходимым условием свободы. Свобода - интуитивно-иррациональна. Бог действует в совершенной свободе, однако он не колеблется и не выбирает. «Непоколебимое, целостное, безраздельное влечение души к Благу - это и есть подлинная свобода. Поэто-

\footnotetext{
17 Татаркевич Вл. Там же. С. 392.

18 Орлов И. Труды святого Максима Исповедника по раскрытию учения о двух волях во Христе. Санкт-Петербург. 1888 г. С. 119.

19 Об учении Максима Исповедника о природных и гномических волях см. Лурье В.М. Там же. С. 404.
} 
му у Максима Исповедника свобода выбора не только не принадлежит к совершенству свободы, а напротив, есть искажение и умаление свободы, - пишет Г. Флоровский. - Колеблется в выборе только грешная, немощная воля» ${ }^{20}$.

В учении Бернарда Клервоского свободный выбор также представляет лишь часть подлинной свободы воли, которую аббат монастыря Клерво условно разделяет на три составляющих:

- свободу выбора;

- свободу суждения (согласия);

- свободу от страданий (свободу наслаждения).

Утратив свободу суждения и свободу от страданий, человек потерял способность к истинной мудрости, которая суть выбор Бога, и возможность непоколебимо держаться этого выбора. «А назначением воли является ее полная обращенность к Богу, всецело преданное и добровольное подчинение Ему. И у этой совершенной праведности должна быть, или даже с ней связана, полнота славы, ибо праведность и слава настолько нераздельны, что нет совершенства праведности иначе, чем в полноте славы, как и полноты славы без совершенной праведности» ${ }^{21}$. Здесь праведность Бернард относит к мудрости, а славой называет «полную мощь» воли.

Этими тремя свободами обладал Адам в раю, но свобода суждения и наслаждения принадлежали ему лишь в низшей степени - как возможность не греиить, и возможность не испытывать страдания. Высшие степени «невозможности грешить» и «невозможности страдать» были Адаму недоступны, иначе он не мог бы согрешить. Эти отрицательные определения «высших степеней свобод» в учении св. Бернарда согласуются с отрицанием преп. Максимом в обоженном человеке гномической воли.

Возвращение утраченной целостности после грехопадения человек не может совершить, пользуясь только одним из оставшихся у него благ - свободой выбора. Как для обожения первого человека требовалось обращение к Божеству, так и спасение грешного человека невозможно без помощи спасительной благодати: «Ведь если бы был такой человек - пишет св. Бернард, - он был бы превыше апостола Павла, который сказал: “Не нахожу в себе силы совершить" $)^{22}$. Энергия благодати необходима для исцеления и восполнения утраченной целостности свободы воли. При этом предполагается не только прямое воздействие Божества, но и сотрудничество самого человека. Православный принцип синергии, о котором говорит Бернард Клервоский в трактате «О благодати и свободе воли», используется Максимом в теории обожения. Здесь преподобный Максим довольно близок к Макарию Египетскому, акцентируя внимание на двух составляющих этого процесса - божественной благодати и человеческой сво-

\footnotetext{
20 Флоровский Г.В. Там же. С. 137.

21 Бернард Клервоский. Там же. С. 171.

22 Бернард Клервоский. О благодати и свободе воли // Средние века. 1982. Вып. 45. С. 278.
}

боде в их существенно равном взаимодействии. Только при гармоническом действии двух этих деятелей человек достигает высшей цели - обожествления своей природы $(\theta \varepsilon \omega \sigma \iota \zeta)$. Как спасение во Христе совершилось силой Его Божества, так и человеку для обожения требуется благодатная помощь, которая нисколько не упраздняет естественных сил человека. Более того, она с необходимостью «предполагает эти силы и в них соответствующую наклонность к восприятию ее» ${ }^{23}$. Так, по Максиму Исповеднику: «У человека два крыла, чтобы возлетать к Богу: свобода и благодать» ${ }^{24}$.

Представляя любовь наиглавнейшей добродетелью, вбирающей в себя все другие виды добродетелей, Максим Исповедник считает ее кратчайшим путем ко спасению: «Любовь есть свершение всяческих благ, будучи верной, неукоснительной и всегда пребывающей, она ведет и приводит живущих в ней к Богу, Наивысшему Благу и Причине всякого блага» ${ }^{25}$. Драгоценнее любви «нет ничего из того, что после Бога» ${ }^{26}$. Именно любовь делает душу богоподобной, позволяет познать дарованное сыновство и соединить ее с Богом: «Стяжавший... любовь стяжал Самого Бога, поскольку Бог есть любовь (1 Ин. 4:16)» ${ }^{27}$. Вера, утвердившаяся в соблюдении божественных заповедей и в подражании Христу, приводит к обретению любви к ближнему и Богу.

Христиане, по степени «стяжания» любви, делятся Максимом Исповедником на три группы:

1. начинающие, которыми управляет страх Божий;

2. преуспевшие, укрепившиеся в надежде на награду, но потому отчасти - корыстные;

3. совершенные, поистине дети Божии, движимые сыновней любовью ${ }^{28}$.

Подобное разделение верующих по их отношению к Богу использует и Бернард Клервоский: «Один славит Бога, потому что Он могуществен, другой — потому что благ для него, третий же - просто потому что Бог благ. Первый — раб, и боится за себя, второй - наемник, и думает только о своей пользе, третий же - сын, и все отдает Отцу. Поэтому и тот, кто боится, и тот, кто ищет своей пользы, оба действуют ради самих себя. Только в сыне есть любовь, которая не ищет своего» ${ }^{29}$.

Следует отметить, что концепция восхождения по ступеням любви в трактовке Бернарда Клервоско-

\footnotetext{
23 Епифанович С.Л. Там же. С. 97.

24 См. Синергия. Проблемы аскетики и мистики Православия: научный сборник / под общей ред. С.С. Хоружего. Москва: Ди-Дик. 1995. C. 108-112.

25 Преп. Максим Исповедник. Послание к Иоанну Кубикуларию о любви // Преп. Максим Исповедник. Творения. Кн. 1. Москва: Мартис. 1993. С. 147.

26 Преп. Максим Исповедник. Вопросоответы к Фалассию // Преп. Максим Исповедник. Творения. Кн. 2. Москва: Мартис. 1993. С. 19.

27 Преп. Максим Исповедник. Главы о любви // Преп. Максим Исповедник. Творения. Кн. 1. Москва: Мартис. 1993. С. 145.

28 См. Омэнн Дж. Христианская духовность в католической традиции. Рим - Люблин: Изд-во Святого Креста. 1994. С. 78.

29 Татаркевич Вл. Там же. С. 107.
} 
го имеет отправную позицию в учении преподобного Максима.

Первой ступенью обретения любви, по Максиму, является отказ от пристрастия ко всему земному и от собственных корыстных желаний. Соблюдение божественных заповедей и подражание Христу позволяют искоренить опаснейшую из страстей - самолюбие. «Подражая Христу, душа способна победить врагов духовной жизни, первейший из которых - себялюбие» ${ }^{30}$. На второй ступени самолюбие заменяется любовью к ближнему. Если человек не любит ближнего, то и Бога любить не может: «Не любящий ближнего не соблюдает заповедь. А не соблюдающий заповедь не может полюбить и Господа» ${ }^{31}$. От любви к ближнему человек поднимается на третью ступень - любовь к Богу. При этом последние две ступени неразделимы, потому что любовь к ближнему «образует любовь к Богу и есть полнота всякой заповеди Божией» ${ }^{32}$.

Бернард Клервоский, сохраняя последовательность ступеней Максима, переосмысливает в психологическом ключе природу «любви к себе». Человек вначале любит себя, и эта «плотская» любовь принадлежит самой природе человека. Такое понимание характерно и для блаженного Августина: «У каждого человека любовь начинается с любви к себе, и может начинаться только так» («Ergo dilectio unicuique a se incipit et non potest nisi a se incipere») (Augustin, Serm. $368, \mathrm{IV}, 4)^{33}$. Созданный Богом, человек «по праву» (божественных заповедей) объектом любви обязан избрать своего Создателя, но «природа» заставляет его по необходимости любить «самого себя, ради себя и, прежде чем все остальное», - пишет Бернард ${ }^{34}$. Этим Бернард Клервоский утверждает неустранимость любви к себе (в этой жизни) как заботы о плоти, ведь даже строгий аскет может обращаться к созерцанию божественных вещей не дольше, чем плоть ему это позволяет. Но любовь к себе носит неупорядоченный характер и часто выходит за пределы необходимости. Метафорически описывая этот процесс, Бернард использует образ реки, заливающей долины - противопоставляя «плотскую» любовь божественной, как дольний мир горнему: «Но если, как обычно и бывает, эта любовь начинает чрезмерно распространяться подобно потоку и, не довольствуясь руслом необходимости, заливает поля вожделения, то тотчас против избыточного разлива встает плотина заповеди, гласящей: Возлюби ближнего твоего, как самого себя» ${ }^{35}$. Любовь к ближнему вводит неупорядоченную любовь к себе в границы справедливости. Сострадание и любовь к другим людям позволяет не только сохранить меру в «самолю-

\footnotetext{
30 См. Омэнн Джс. Там же. С. 78.

31 Преп. Максим Исповедник. Там же. С. 98.

32 Преп. Максим Исповедник. Слово о подвижнической жизни // Преп. Максим Исповедник. Творения. Кн. 1. Москва: Мартис. 1993. C. 77.

33 См. Бернард Клервоский. Трактаты. О любви к Богу. О благодати и свободном выборе. Санкт-Петербург: Изд-во РХГА. 2009. С. 121

34 См. Gilson E. Ibid. P. 37.

35 Бернард Клервоский. Там же. С. 85.
}

бии», но и приводит к общности с другими душами. На этой ступени уникальность отношения души к Богу не отделяет ее от других душ. Человеческая любовь ищет уже не своей пользы, а того, что полезно «созданиям Божьим», а значит и Богу. Бернард считает, что для того, «чтобы любовь к ближнему была совершенно праведной, необходимо, чтобы в ней был Бог» ${ }^{36}$. На третьей ступени человек бескорыстно любит Бога, и любит справедливо, ибо «Он прежде возлюбил нас» ${ }^{37}$.

В отличие от трех «ступеней любви», представленных в учении Максима, в своей схеме восхождения св. Бернард вводит еще одну ступень, высшую, на которой любовь полностью соединяет человека с Божественной волей. Эта ступень представляет собой преображение, выход за пределы любви, обожествление. Но четвертая ступень доступна в этой жизни лишь на краткий миг блаженным и святым. Здесь Бернард говорит об экстазе, обожении: «... так же как раскаленное железо теряет свой прежний вид, уподобляясь огню, а пронизанный солнечными лучами воздух преображается в лучезарность, будто не освещен, но сам излучает свет, так же и у святых всякое человеческое чувство неизреченным образом растворяется и полностью изливается в волю Божию» ${ }^{38}$.

Близость идей св. Бернарда и Максима Исповедника в этом вопросе подчеркивает буквальное сходство некоторых фраз, заимствованных Бернардом Клервоским у преп. Максима. Во второй главе сочинения «Амбигвы к Иоанну» преп. Максим пишет: «... добровольно приемля по произволению спасительное определение, дабы все оно окачествовалось всем определяющим его, так чтобы совершенно более не желало определяемое возможности познаваться по себе самому всецело, но по определяющему его, как воздух, полностью освещенный светом, и железо огнем все иеликом раскаленное, и другое тому подобное» ${ }^{39}$. Сами же образы соединения воздуха со светом, железа с огнем и воды с вином восходят к стоической философии.

Подчеркнем, что в учении Бернарда Клервоского «Божья любовь полна лишь в Троице, человеческая - лишь в соучастии Бога, души и ближнего. С другой стороны, Божья воля или Божья любовь во Христе самозабвенно обратилась на людей, ставших Его братьями по плоти и Его сынами. Поэтому уподобление Богу, как уподобление Христу, есть превращение воли человека в волю Христову, т.е. деятельная любовь к ближним ${ }^{40}$. Таким образом, анализ понятия любви в учении Бернарда Клервоского приводит к идее Церкви как союза верующих в милосердии, деятельной любви и заботе о нуждах ближних. Для самого Бернарда и последующих католических мистиков обретение Бога

\footnotetext{
36 Орлов И. Там же. С. 89.

37 Бернард Клервоский. Там же. С. 51.

38 Бернард Клервоский. Там же. С. 25.

39 Преп. Максим Исповедник. Амбигвы к Иоанну // http://www. romanitas.ru/Actual/AmbiguaKIoannu.htm. Дата обращения 201606 23.

40 Карсавин Л.П. Там же. С. 16.
} 
в глубинах души, и личностная встреча с Ним без посредников ни в коем случае не противопоставляются церковной жизни, наоборот, невозможны без нее.

В гносеологии Максим основывается на религиозном чувстве, которое гармонично соединяет с рассудочной рефлексией и диалектикой. Если говорить о примате веры или знания, то в учении Максима, как справедливо утверждает С. Епифанович, «не столько вера рационализируется, сколько философия поглощается верой ${ }^{41}$. По своим воззрениям на познание Бернард Клервоский близок преп. Максиму, признавая несостоятельность нашего разума в постижении, как порядка мирового бытия, так и сущности вещей. Чувственное познание знакомит лишь с внешней стороной мира, мысленное - открывает истинно-духовную сущность, но в предельном своем основании все же непостижимую и необъяснимую, перед которой разум останавливается в полном бессилии. Следовательно, требуется с необходимостью допустить нечто недостижимое для тварного разума, нечто иррациональное, «премысленное», что можно принять лишь верой. С. Епифанович отмечает: «В своих созерцаниях Максим Исповедник ищет точек опоры не в каких-либо неоспоримых данных рассудочного сознания (вроде «сogito, ergo sum»), а в таинственных фактах внутреннего мистического опыта, возвышающегося над рамками естественного (философского) познания и досязающего до премысленного постижения высшей реальности» ${ }^{42}$.

Такой подход характерен и для св. Бернарда, отдающего предпочтение мистическому созерцанию: «Велик тот, - пишет средневековый мистик, - кто чувствами и чувственными предметами пользуется ко благу своему и ко благу других; не менее велик тот, кто, философствуя, от чувственного возвышается к сверхчувственному; но особенно велик тот, кто, презирая чувства и чувственные предметы не постепенно, но через внезапное восхищение возлетает на высоту» ${ }^{43}$. Доминанта интроспекции и религиозного опыта в гносеологии Бернарда Клервоского выступает связующим конструктом проблемного поля онтологической, антропологической, этической тематики, в соответствии с чем термин «philosophia» трактуется св. Бернардом как определение интеллектуальных исследований христианами истин веры. В этой связи, иерархию гносеологических методов богопознания в учении Бернарда Клервоского, как и в учении преп. Максима, венчает созерцание, - определяющий конструкт мистической методологии.

В завершение исследования мистико-гносеологических параллелей в учениях средневековых монахов - византийского неоплатоника и французского мистика, приведем цитату из произведения Томаса Мертона, крупнейшего католического писателя XX века, монаха-трапписта, одного из пионеров современного ме-

\footnotetext{
41 Епифанович С.Л. Там же. С. 53.

42 Епифанович С.Л. Там же. С. 53.

43 См. Вертеловский А.Ф. Там же. С. 119-120.
}

жрелигиозного диалога: «Нет ничего более чуждого созерцанию, чем декартовское cogito ergo sum - «я мыслю, значит я существую». Это декларация отчужденного человека, изгнанного из собственных духовных глубин, вынужденного искать утешения в доказательстве собственного существования, основанном на наблюдении, что он «мыслит». [...] Для созерцающего нет cogito «я мыслю» и нет ergo «а поэтому», но только SUM - «я есмь». Не в смысле тщетного утверждения нашей индивидуальности как окончательно реальной, но в смиренном сознании нашего скрытого существа как личности, в которой, с беспредельной добротой и непоколебимой властью, живет Бог» ${ }^{44}$.

Резюмируя вышесказанное, можно говорить о том, что философско-религиозные построения Максима Исповедника, рассмотренные нами выше, имеют христоцентрический характер и основываются на теологеме Боговоплощения Слова. Воплощение для преп. Максима - средоточие мирового бытия, идея, лежащая в основании мира. Бог создает мир и в нем человека, чтобы Бог стал человеком и человек стал Богом. «Спаситель - это предел всякого мысленного и духовного движения. Для Него были сотворены все века вместе со всем, что они содержат, и этот синтез Бога и мира является Божественной идеей, которая древнее и таинственнее всего и в которой только и заключается путь и способ существования всего» ${ }^{45},-$ пишет Максим, согласовывая развертывание мира и движение конечного к возвращению в Божественное единство через богочеловечество Христа. Заповеди любви, принесенные Им человечеству, открыли путь самореализации в свободе, позволяющий от естественной богообразности перейти к состоянию духовно-приобретенного богоподобия.

Влияние идей Максима Исповедника в учении Бернарда Клервоского прослеживается в нескольких взаимосвязанных аспектах:

1) православная теория синергии, разработанная преподобным Максимом в эпоху монофелитских споров, используется Бернардом в концепции о свободе воли и в теории соединения с Богом посредством слияния двух воль (Божественной и человеческой) в любви;

2) богословие Бернарда, как и Максима Исповедника - христоцентрично, а их философские построения - антропоцентричны и предполагают личностное начало как в метафизике, так и в теории обожения;

3) в гносеологии преобладает релятивистская точка зрения: истинное познание возможно лишь с обретением любви к Богу, которая и приводит к мистическому единению с Абсолютом, где высшая реальность открывается в совершенном слиянии познающего с познаваемым;

4) любовь к Богу, как величайшая из добродетелей, представляет собой не только необходимую осно-

44 Мертон T. Новые семена созерцания. Москва: «SALVEMUS!». 2010. C. 11-12.

45 Преп. Максим Исповедник. Вопросоответы к Фалассию // Преп. Максим Исповедник. Творения. Кн. 2. Москва: Мартис. 1993. С. 62. 
ву мистического восхождения, но и цель всякого духовного устремления человека. Восходя по «ступеням любви», человек достигает обожения, соединяя свою волю с Божественной.

Таким образом, эксплицированные точки соприкосновения доктрин христианских мыслителей позволяют утверждать, что Бернард Клервоский в своих воззрениях следует византийской неоплатонической традиции преимущественно в трактовке преподобного Максима Исповедника. Можно предположить, что в этом и заключается причина определенного контраста мистики «Божественной любви» св. Бернарда с предыдущими (например, Эриугеной) и последующими (Экхарт) мистиками «Божественного мрака», вдохновлявшимися Дионисием Ареопагитом. Связывая учение Максима о двух волях во Христе с динамикой восстановления человека, Бернард Клервоский формирует собственный взгляд на проблему возвращения челове- ка к Богу в синергийном взаимодействии их воль. Исходя из предложенной Максимом структурированной последовательности восхождения, как внутреннего пути духовного освобождения от эгоцентрической зависимости, Бернард определяет высшую форму любви в мистическом единении с Богом, где обретение абсолютной свободы в интуитивно-иррациональном подчинении Божеству представляется высшей целью человеческой жизни. Синтезируя энергией спекулятивной мысли традиционные элементы Священного Писания, древнецерковной мистики и святоотеческой традиции, аббат монастыря Клерво формирует оригинальное учение, в котором важной составной частью теоретического фундамента являются идеи византийского богослова Максима Исповедника, что подтверждает гипотезу о неразрывности философско-богословской традиции в монашеской культуре Средневековья первой половины XII века.

\section{Источники и литература}

Бернард Клервоский. О благодати и свободе воли // Средние века. 1982. Вып. 45.С. 265-303.

Бернард Клервоский. Трактаты. О любви к Богу. О благодати и свободном выборе. Санкт-Петербург: Изд-во РХГА. 2009.

Вертеловский А.Ф. Западная средневековая мистика и отношение ее к католичеству. Харьков: Типография Окружного Штаба. 1888.

Епифанович С.Л. Преп. Максим Исповедник и византийское богословие. Москва: Мартис. 1996.

Иоанн Скот Эриугена. Жизнь и творения // http://anthropology. rchgi.spb.ru/eriugena/eriugena_b.htm/. Дата обращения 20160620.

Карсавин Л.П. Католичество. Петроград: Изд-во «Огни». 1918.

Лейн Т. Христианские мыслители. Санкт-Петербург: Мирт. 1997.

Лурье В.М. История Византийской философии. Формативный период. Санкт-Петербург: Ахіоิта, 2006

Преп. Максим Исповедник. Вопросоответьл к Фалассию // Преп. Максим Исповедник. Творения. Кн. 2. Москва: Мартис. 1993. С. 21-209.

Преп. Максим Исповедник. Главы о любви // Преп. Максим Исповедник. Творения. Кн. 1. Москва: Мартис. 1993. C. 96-145.

Преп. Максим Исповедник. Послание к Иоанну Кубикуларию о любви // Преп. Максим Исповедник. Творения. Кн. 1. Москва: Мартис. 1993. С. 146-153.

Преп. Максим Исповедник. Слово о подвижнической жизни // Преп. Максим Исповедник. Творения. Кн. 1. Москва: Мартис. 1993. С. 75-95.
Прот. И. Мейендорф. Святой Григорий Палама и православная мистика. Учение об обожении: Свят. Григорий Нисский и преп. Максим // http://predanie.ru/lib/ book/129694/\#toc1.Дата обращения 20160623.

Мертон Т. Новые семена созерияания. Москва: «SALVEMUS!». 2010.

Омэнн Дж. Христианская духовность в католической традиции. Рим - Люблин: Изд-во Святого Креста. 1994.

Орлов И. Труды святого Максима Исповедника по раскрытию учения о двух волях во Христе. Санкт-Петербург. 1888 г.

Преп. Максим Исповедник. Амбигвы к Иоанну // http://www. romanitas.ru/Actual/AmbiguaKIoannu.htm. Дата обращения 20160623.

Синергия. Проблемы аскетики и мистики Православия: научный сборник / под общей ред. С.С. Хоружего. Москва: Ди-Дик. 1995.

Татаркевич Вл. История философии. Т. 1. Античная и средневековая философия. Пермь: Изд-во Пермского университета. 2000.

Флоровский Г.В. Византийские Отщы V-VIII веков: из чтений в Православном богословском институте в Париже. Москва: Паломник. 1992.

Чорноморець Ю.П. Візантійський неоплатонізм від Діонісія Apeопагіта до Геннадія Схоларія. Київ: Дух і Літера. 2010.

Gilson E. The mystical theology of Saint Bernard. New York: Sheed \& Ward. 1940.

Rozmiar artykułu: 0,9 arkusza wydawniczego 
ISSN 1508-7719

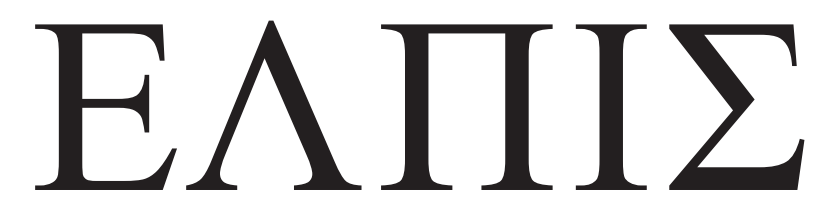

CZASOPISMO TEOLOGICZNE KATEDRY TEOLOGII PRAWOSŁAWNEJ UNIWERSYTETU W BIAŁYMSTOKU

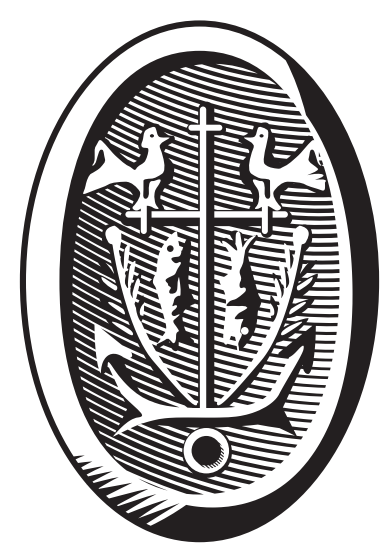

ADRES REDAKCJI

15-097 Białystok, ul. M. Skłodowskiej-Curie 14 tel. 85 745-77-80, e-mail: redakcja@elpis.edu.pl www.elpis.uwb.edu.pl 